\title{
OBOWIĄZEK SZCZEPIEŃ OCHRONNYCH - ANALIZA PRAWNOMEDYCZNA
}

\begin{abstract}
Streszczenie. Autorzy analizują obowiązek szczepień ochronnych zawarty w ustawie o zapobieganiu i zwalczaniu chorób zakaźnych u ludzi. Analiza dotyczy zagadnień związanych z prawem konstytucyjnym, administracyjnym oraz karnym, ujętych w kontekście obecnego stanu wiedzy medycznej. Praca zawiera postulaty de lege ferenda dotyczące usprawnienia sposobu egzekwowania tego obowiązku, które w opinii autorów poprawiłyby ochronę życia i zdrowia ludzkiego. Wprowadzenie takich zmian byłoby rzeczowe w kontekście rosnącego problemu odmowy poddawania się szczepieniom, zwłaszcza w odniesieniu do dzieci. Zaniedbanie tej sytuacji może doprowadzić do poważnych negatywnych skutków w przyszłości.
\end{abstract}

Slowa kluczowe: prawo medyczne, szczepienia, obowiązek szczepień, narażenie na niebezpieczeństwo, zapobieganie chorobom zakaźnym.

Tematyka obowiązkowych szczepień ochronnych staje się coraz popularniejsza w publicznej debacie. Rosnącym zainteresowaniem cieszą się różnego rodzaju ruchy kontestujące rzeczony obowiązek, charakteryzujące się kwestionowaniem ustaleń naukowych z dziedziny wakcynologii, które dotychczas były powszechnie akceptowane. Jakość używanych w dyskusji argumentów pozostawia wiele do życzenia, stąd próba rzeczowego, naukowego przedstawienia tej tematyki z prawnomedycznego punktu widzenia. Niewątpliwie temat ten pozostaje w ścisłym związku z samym pojęciem intymności człowieka. Nie da się bowiem ukryć, że obowiązek szczepień ingeruje w pewien sposób w wolność jednostki, zmuszając ją do poddania się zabiegowi medycznemu, nawet jeżeli zabieg ten pozostaje zwykle daleki od komplikacji. Problemem pojawiającym się coraz częściej jest również brak wyrażania zgody na szczepienie dzieci pozostających pod opieką danej osoby.

Obowiązek szczepień ochronnych jest wyrażony wprost w przepisach ustawy z dnia 5 grudnia 2008 r. o zapobieganiu oraz zwalczaniu chorób zakaźnych u ludzi (tekst jedn. Dz.U. z 2008 r. Nr 234, poz. 1570 ze zm., dalej: u.z.z.). Art. 5 tej ustawy stanowi, iż ,osoby przebywające na terytorium Rzeczypospolitej Polskiej są obowiązane na zasadach określonych w ustawie do poddania

\footnotetext{
*Uniwersytet Medyczny w Lodzi, Wydział Lekarski, michal_fita@wp.pl.

** Okręgowa Izba Radców Prawnych w Łodzi, bartlomiejkrol7@gmail.com.
} 
się [...] szczepieniom ochronnym". Obowiązek ten zaś jest skonkretyzowany w art. 17 ustawy, opisującym szczegółową procedurę poddawania się szczepieniu. Szczegółowe dane, takie jak wykaz chorób zakaźnych objętych obowiązkiem i osób podlegających obowiązkowi, znajdują się w odpowiednim rozporządzeniu ministra właściwego ds. zdrowia. Na dziś jest to rozporządzenie Ministra Zdrowia z dnia 18 sierpnia $2011 \mathrm{r}$. w sprawie obowiązkowych szczepień ochronnych (tekst jedn. Dz.U. z 2011 r. Nr 182, poz. 1086 ze zm.). Istotne informacje dotyczące samych szczepionek znajdują się z kolei w odpowiednim komunikacie Głównego Inspektora Sanitarnego, którym jest Program Szczepień Ochronnych na dany rok.

Legalna definicja pojęcia szczepienia ochronnego znajduje się w art. 2 pkt 26 u.z.z. Zgodnie z nią szczepienie ochronne to „podanie szczepionki przeciw chorobie zakaźnej w celu sztucznego uodpornienia przeciwko tej chorobie". Według art. 17 ust. 6 u.z.z. szczepienia ochronne są przeprowadzane przez lekarzy, felczerów, pielęgniarki, położne i higienistki szkolne. Aby odpowiedzieć na pytanie, czy w ogóle można zgodnie z prawem nie wyrazić zgody na poddanie się szczepieniu, należy najpierw zbadać, czy udzielenie szczepienia będzie świadczeniem zdrowotnym w rozumieniu ustawy z dnia 9 grudnia 1996 r. o zawodach lekarza i lekarza dentysty (tekst jedn. Dz.U. z 1997 r. Nr 28, poz. 152 ze zm.). Art. 32 tej ustawy wskazuje bowiem, że świadczenie zdrowotne może być udzielone przez lekarza tylko wtedy, gdy pacjent wyrazi na nie zgodę - z zastrzeżeniem ustawowych wyjątków. Definicja legalna świadczenia zdrowotnego znajduje się w ustawie z dnia 15 kwietnia $2011 \mathrm{r}$. o działalności leczniczej (tekst jedn. Dz.U. z 2011 r. Nr 112, poz. 654 ze zm.). Jej art. 2 pkt 10 wskazuje, że świadczenia zdrowotne to wszelkie „działania służące zachowaniu, ratowaniu, przywracaniu lub poprawie zdrowia oraz inne działania medyczne wynikające z procesu leczenia lub przepisów odrębnych regulujących zasady ich wykonywania”. Identyczna definicja świadczenia zdrowotnego znajdowała się w poprzednim stanie prawnym w ustawie z dnia 30 sierpnia 1991 r. o zakładach opieki zdrowotnej (Dz.U. z 1991 r. Nr 91, poz. 408). Ta nieobowiązująca już ustawa wskazywała w art. 3 przykładowe świadczenia zdrowotne, w pkt 12 wskazując szczepienia ochronne. Należy się zgodzić z poglądem Rafała Kubiaka, że w takim stanie rzeczy nie istnieją powody, żeby katalog przykładowych świadczeń zdrowotnych nie zachowywał aktualności w świetle ustawy o działalności leczniczej (Kubiak 2017, 20). Wobec tego należy przyjąć założenie, iż zawsze przy dokonywaniu szczepienia ochronnego wymagane jest wyrażenie zgody pacjenta na takowy zabieg. Zgoda pacjenta jest tu rozumiana jako pozwolenie wydane przez pacjenta lekarzowi na „naruszenie integralności jego osoby w ustalonym zakresie” (Nesterowicz 2016, 158). Zgoda taka uchyla bezprawność działania lekarza. Co jest istotne, za pacjenta małoletniego zgodę wyraża jego przedstawiciel ustawowy, zgodnie $\mathrm{z}$ art. 32 ust. 2 ustawy o zawodzie lekarza i lekarza dentysty. $Z$ drugiej strony 
ta regulacja znajduje się w ustawie z dnia 6 listopada 2008 o prawach pacjenta i Rzeczniku Praw Pacjenta (tekst jedn. Dz.U. z 2009 r. Nr 52, poz. 417 ze zm.). Art. 16 tej ustawy przyznaje pacjentowi wprost prawo podmiotowe do odmowy wyrażenia zgody na zabieg medyczny. Jeśli uznać, że pacjent ma prawo nie zgodzić się na zaszczepienie siebie lub swojego dziecka, zastanowić się należy, czy taki brak zgody można przełamać.

Ustawa o zawodzie lekarza i lekarza dentysty przewiduje w art. 33 i art. 34 wyjątki od sytuacji, kiedy to świadczenia można udzielić z pominięciem uzyskania zgody pacjenta. Upraszczając, dotyczą one stanów faktycznych, w których pacjent wymaga natychmiastowej pomocy medycznej i występuje zagrożenie utraty życia bądź wystąpienia ciężkiego uszczerbku na zdrowiu. Jako takie nie będą raczej dotyczyć sytuacji, w której pacjent jest poddany szczepieniu ochronnemu. Rzecz jasna można wskazać nietypowy stan faktyczny, w którym pacjent potencjalnie zarażony wścieklizną, w sytuacji pokąsania przez chore zwierzę, odmawia poddania się szczepieniu i wówczas uzyskać zastępczą zgodę wydaną przez sąd opiekuńczy. Możliwość przełamania braku zgody pacjenta jest także wskazana w art. 36 pkt 1 u.z.z., niemniej dotyczy to osób, u których ,podejrzewa się lub rozpoznano chorobę szczególnie niebezpieczną i wysoce zakaźną, stanowiącą bezpośrednie zagrożenie dla zdrowia lub życia innych osób”. Nie będzie to zatem dotyczyć osób odmawiających poddania się szczepieniu prewencyjnemu. Należy zatem dojść do wniosku, że jeśli zdrowa osoba odmawia poddania siebie lub swojego dziecka świadczeniu zdrowotnemu w postaci szczepienia ochronnego, to sam lekarz nie ma bezpośredniej możliwości przełamania braku takiej zgody. Nie ma znaczenia, że orzecznictwo, jak przykładowo wyrok Sądu Apelacyjnego w Warszawie z dnia 19 października 2016 r. (VII SA/Wa 2542/15, LEX nr 2159952), wskazuje na bezprawność takiej zgody, jeśli pacjent nie przychodzi na szczepienie albo nie przyprowadza na nie dziecka.

Jeśli zatem nie ma możliwości, aby sam lekarz przełamał opór odmawiającego wyrażenia zgody rodzica, to należy zastanowić się, jakie są inne prawne metody wyegzekwowania obowiązku poddania się szczepieniu ochronnemu. Obowiązek szczepień ochronnych, jak wskazuje ustalona linia orzecznicza (zob. wyr. Wojewódzkiego Sądu Administracyjnego w Poznaniu z dnia 1 czerwca 2017 r., IV SAB/Po 22/17, LEX nr 2341062; wyr. Wojewódzkiego Sądu Administracyjnego w Krakowie z dnia 14 lutego 2013 r., III SA/Kr 460/12, LEX nr 1343450), jest obowiązkiem wynikającym z mocy samego prawa. Z tej przyczyny należy zgodzić się z poglądem Naczelnego Sądu Administracyjnego (II OSK 32/11, LEX nr 852219), że nie istnieje podstawa prawna do wydania decyzji administracyjnej, na mocy której należałoby poddać się obowiązkowi szczepienia. Nie ulega także wątpliwości, że jest to obowiązek faktyczny, o charakterze niepieniężnym. Będzie on jako taki podlegał egzekucji administracyjnej, co wynika z art. 3 ustawy z dnia 17 czerwca 1966 r. o postępowaniu egzekucyjnym w administracji (Dz.U. z 1966 r. Nr 24, poz. 151 ze zm., dalej: u.p.e.a.). Przepis ten wskazuje 
bowiem, że egzekucja administracyjna może być prowadzona z obowiązków wynikających z przepisu prawa.

Problem pojawia się jednak przy ustaleniu, jaki organ będzie właściwy do przeprowadzenia egzekucji tego obowiązku. Ustawa o zapobieganiu i zwalczaniu chorób zakaźnych u ludzi nie wskazuje, który podmiot ma egzekwować obowiązek szczepień. Wydawałoby się, że powinna tego dokonywać Państwowa Inspekcja Sanitarna. Art. 2 ustawy z dnia 14 marca 1985 r. o Państwowej Inspekcji Sanitarnej (Dz.U. z 1985 r. Nr 12, poz. 49 ze zm.) wskazuje na kompetencję tego organu do ,prowadzenia działalności zapobiegawczej i przeciwepidemicznej w zakresie chorób zakaźnych". W art. 5 tej ustawy jest także przewidziana możliwość wydawania przez Państwową Inspekcję Sanitarną zarządzeń i decyzji. Jednak, jak wskazane zostało powyżej, obowiązek szczepień nie powstaje mocą decyzji żadnego organu. Dlatego też, zgodnie z art. 20 u.p.e.a., organem właściwym do prowadzenia egzekucji nie może być Państwowa Inspekcja Sanitarna. Organ ten jest uprawniony do prowadzenia egzekucji jedynie „W odniesieniu do obowiązków wynikających z wydawanych w zakresie swojej właściwości decyzji i postanowień". Organ tej inspekcji mógłby wydawać postanowienie dotyczące „ustalania zakresów i terminów szczepień ochronnych”. W tej kwestii, na podstawie art. 17 ust. 11 u.z.z., Główny Inspektor Sanitarny wydaje Program Szczepień Ochronnych na dany rok w formie komunikatu. Akt jako taki nie jest jednak źródłem prawa powszechnie obowiązującego i nie może być podstawą wydania decyzji administracyjnej przez organy podległych mu inspekcji sanitarnych. $Z$ racji tego, na mocy utrwalonego w orzecznictwie poglądu (np. wyr. Naczelnego Sądu Administracyjnego z dnia 6 kwietnia 2011 r., II OSK 32/11, LEX nr 852219), organem właściwym do egzekwowania obowiązku szczepienia będzie wojewoda. Środkami, które wojewoda mógłby potencjalnie zastosować zgodnie $\mathrm{z}$ art. 1a pkt $12 \mathrm{~b}$ u.p.e.a., będą: grzywna w celu przymuszenia oraz przymus bezpośredni.

W praktyce odnotowywano sytuacje, w których to organ inspekcji sanitarnej wydawał decyzje, jednak zgodnie z wyrokiem Naczelnego Sądu Administracyjnego z dnia 6 kwietnia 2011 r. (II OSK 32/11, LEX nr 852219) jest to sprawa „niepodlegająca autorytatywnej konkretyzacji w tej formie prawnej”. Decyzja taka będzie zatem wydana $\mathrm{z}$ rażącym naruszeniem prawa i powinna zostać unieważniona. Zgodzić się jednak należy z Pawłem Danielem, że znacznie bardziej zasadne byłoby egzekwowanie tego obowiązku przez właściwy organ Państwowej Inspekcji Sanitarnej na danym szczeblu jednostki terytorialnej, stąd poprzeć trzeba postulat tego autora o konieczności stosownej nowelizacji przepisów u.p.e.a. (Daniel 2014, 51).

Jak było wskazane we wstępie, obowiązek szczepień niewątpliwie wiąże się z pewnym ograniczeniem praw i wolności obywatelskich. W związku z tym może on funkcjonować w systemie prawnym jedynie na zasadach przedstawionych w art. 31 Konstytucji Rzeczypospolitej Polskiej z dnia 2 kwietnia 1997 r. 
(Dz.U. z 1997 r. Nr 78, poz. 483 ze zm.). Przepis ten wprowadza zasadę proporcjonalności, wskazując, iż ograniczanie konstytucyjnych praw i wolności może nastąpić jedynie w drodze ustawy oraz jedynie, gdy to konieczne w demokratycznym państwie dla, między innymi, ,zdrowia i moralności publicznej”. Jak jest powszechnie akceptowane (Garlicki 2017), wymaga się, aby każdy przepis potencjalnie naruszający wolność jednostki przeszedł test proporcjonalności, to znaczy, żeby dało się w sposób pozytywny odpowiedzieć na trzy pytania, zawarte już w orzeczeniu Trybunału Konstytucyjnego z dnia 26 kwietnia 1995 r. (K 11/94, LEX nr 25538):

1) czy wprowadzona regulacja ustawodawcza jest w stanie doprowadzić do zamierzonych skutków;

2) czy regulacja jest niezbędna dla ochrony interesu publicznego, z którym jest powiązana;

3) czy efekty wprowadzone przez regulację pozostaną w proporcji do ciężarów nałożonych przez nią na obywatela.

Po pierwsze, należy uznać, że ustawa prowadzi do zamierzonego skutku - zapobiegania rozprzestrzenianiu się chorób zakaźnych. Badania kliniczne dostarczyły bardzo mocnych dowodów potwierdzających skuteczność szczepień obowiązkowych, z reguły przekraczającą 90\% (Ściubisz, Rywczak 2017, 40-51). Oznacza to, że zaszczepiona osoba ma kilkunasto-, kilkudziesięciokrotnie mniejsze prawdopodobieństwo rozwinięcia choroby zakaźnej, czyli - szczepiąc, z dużym prawdopodobieństwem zapobiega się wystąpieniu choroby u szczepionej jednostki. W przypadku masowych szczepień następstwem spadku prawdopodobieństwa zachorowania wśród wielu jednostek jest spadek częstości występowania choroby w populacji. Znalazło to potwierdzenie w danych epidemiologicznych dla populacji polskiej po wprowadzeniu kolejnych obowiązkowych szczepień - w przypadku praktycznie każdej z chorób obserwowany był gwałtowny spadek zachorowalności po wprowadzeniu obowiązku szczepień ochronnych (Tabela 1).

Po drugie, wydaje się, że obowiązek szczepień jest niezbędny do zapobieżenia szerzeniu się chorób zakaźnych. Aby program szczepień odniósł sukces, konieczny jest odpowiedni poziom wyszczepialności w społeczeństwie. Jeżeli wyszczepialność jest niska, to chronione są jedynie jednostki szczepione. W takiej sytuacji zachorowalność nieco spada, ale transmisja chorób dalej swobodnie zachodzi w populacji nieszczepionej. W przypadku wysokiej wyszczepialności pojawia się efekt odporności gromadnej. Jednostki nieszczepione bądź nie wytwarzające odpowiedniego poziomu odporności nie mają możliwości zarażenia się chorobą, gdyż w ich otoczeniu brakuje nosicieli patogenu, a transmisja choroby zostaje przerwana. Odsetek osób zaszczepionych w danej populacji, przy osiągnięciu którego choroba zakaźna przestaje się rozprzestrzeniać, nazywany jest progiem odporności gromadnej i jest różny w odniesieniu do różnych chorób. Zależy między innymi od zakaźności patogenu, drogi jego przenoszenia, kontaktów między przedstawicielami populacji, aczkolwiek modele matematyczne 
i obserwacje epidemiologiczne wskazują że jego wartość wynosi od 75\% do 95\% (Fine 1993, 265-302). Odpowiednio wdrożony program szczepień pozwala nawet na ogólnoświatową eradykację choroby zakaźnej. Udało się to osiągnąć w przypadku ospy prawdziwej (Fenner i in. 1988), a obecnie bardzo blisko wydaje się być eradykacja poliomyeltis. Konieczna jest tutaj wysoka wyszczepialność, gwarantowana obowiązkiem szczepień.

Po trzecie, należy sprawdzić, czy wyżej wymienione pozytywne efekty działania szczepionek pozostają w odpowiedniej proporcji do ciężarów nałożonych na obywatela. Wprowadzenie szczepień wiąże się z pewnymi negatywnymi efektami - to przede wszystkim podnoszony przez przeciwników szczepień problem występowania niepożądanych odczynów poszczepiennych (dalej: NOP). Według definicji legalnej, zawartej w ustawie o zapobieganiu i zwalczaniu chorób zakaźnych u ludzi, NOP jest niepożądanym objawem chorobowym, pozostającym w związku czasowym z wykonanym szczepieniem ochronnym.

Katalog objawów niepożądanych, a także sposób ustalania związku czasowego jest określony w rozporządzeniu Ministra Zdrowia z dnia 21 października 2010 r. (Dz.U. z 2010 r. Nr 254, poz. 1711). Większość objawów można uznać za NOP, jeśli wystąpiły w ciągu 4 tygodni od momentu zaszczepienia. Rozporządzenie podaje katalog 24 objawów uznawanych za NOP, od zgonu i zapalenia mózgu czy wstrząsu anafilaktycznego po względnie niegroźne, jak powiększenie węzłów chłonnych czy ropień w miejscu podania szczepionki. Według klasyfikacji Państwowego Zakładu Higieny wyróżnić można także NOP ciężkie, których rezultatem jest stan bezpośredniego zagrożenia życia albo znaczny lub trwały uszczerbek na zdrowiu (Czarkowski i in. 2016).

W kontekście powikłań poszczepiennych narażane dobro jest tym samym, które ustawodawca chroni - potencjalnie narażone zostaje zdrowie i życie w celu ochrony zdrowia i życia. Dlatego też należy się przyjrzeć porównaniu negatywnych skutków szczepień oraz liczby chorób, którym w tym czasie udało się dzięki szczepieniom zapobiec.

W roku 2015 zarejestrowano w Polsce 2111 przypadków NOP. Jedynie trzy z nich były ciężkimi NOP, w tym doszło do jednego zgonu. W przypadku tego zgonu w momencie ukazania się cytowanej publikacji Państwowego Zakładu Higieny nie zakończono jeszcze postępowania wyjaśniającego, czy poza zbieżnością czasową istnieją inne przesłanki pozwalające na powiązanie go ze szczepieniem.

Na podstawie częstości występowania chorób zakaźnych przed wprowadzeniem szczepień ochronnych i ich śmiertelności w warunkach współczesnej opieki zdrowotnej można szacować że dzięki obowiązkowi tych szczepień rocznie zapobiega się ponad 400000 zachorowań i 3-5 tys. zgonów (Tabela 1).

${ }^{1} \mathrm{~W}$ powyższym szacunku nie uwzględniono gruźlicy, w przypadku której szczepionka wykazuje niską skuteczność. Obecnie szczepi się jedynie noworodki w pierwszej dobie życia, zapewniając ochronę maksymalnie do 10-15 roku życia, a celem szczepień jest nie tyle powstrzymanie transmisji gruźlicy, co raczej złagodzenie jej przebiegu wśród dzieci. Przede wszystkim chodzi 
Tabela 1. Epidemiologia chorób zakaźnych objętych obowiązkiem szczepień ochronnych

\begin{tabular}{|c|c|c|c|c|c|c|}
\hline $\begin{array}{l}\text { Choroba } \\
\text { zakaźna }\end{array}$ & 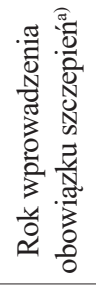 & 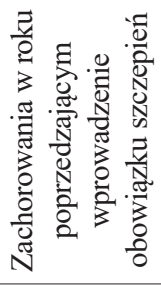 & 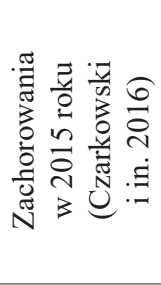 & 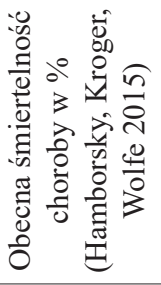 & 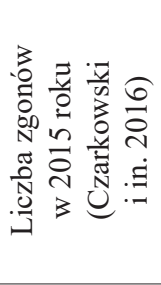 & 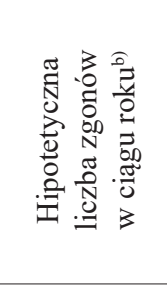 \\
\hline Błonica & 1954 & 34007 & 0 & $5-10$ & 0 & $1700-3400$ \\
\hline Odra & 1975 & 70857 & 41 & 0,2 & 0 & 142 \\
\hline $\begin{array}{l}\text { Poliomyeltis } \\
\text { (postać } \\
\text { porażenna) }\end{array}$ & 1959 & 6090 & 0 & $2-5$ & 0 & $122-305$ \\
\hline Tężec & 1954 & 441 & 12 & 11 & 0 & 49 \\
\hline Świnka & 2002 & $103138^{c)}$ & 2208 & - & 0 & - \\
\hline Krztusiec & 1960 & 70195 & 4956 & 0,2 & 0 & 140 \\
\hline Różyczka & 1989 & $119281^{\mathrm{d}}$ & 2026 & - & 0 & - \\
\hline $\begin{array}{l}\text { Haemophilus } \\
\text { influenzae }\end{array}$ & 2007 & 39 & 62 & $1,5-2,5$ & 0 & 0 \\
\hline WZW B & 1996 & 9034 & $3518^{\mathrm{e})}$ & $9^{f)}$ & $308^{\mathrm{g})}$ & 813 \\
\hline $\begin{array}{l}\text { Łącznie } \\
\text { bez gruźlicy }\end{array}$ & - & 413082 & 12823 & - & 308 & $2966-4849$ \\
\hline Gruźlica & 1955 & $85529^{\text {h) }}$ & 6430 & $8^{\text {i) }}$ & $526^{\mathrm{j})}$ & 6842 \\
\hline Łacznie & - & 498611 & 19253 & - & 834 & $9808-11691$ \\
\hline
\end{tabular}

a) Zob. Szczepienia (2018).

b) Obliczona przy założeniu, że liczba zachorowań jest taka, jak w roku poprzedzającym wprowadzenie obowiązku szczepień, a śmiertelność równa podanej w tabeli szacowanej śmiertelności obecnej.

c) Średnia czteroletnia z lat 1997-2000. Użyto średniej, ponieważ przed wprowadzeniem obowiązku szczepień okresowy wzrost liczby zachorowań na świnkę występował co 3-4 lata.

d) Średnia pięcioletnia z lat 1984-1988. Skorzystano ze średniej, ponieważ różyczka przed wprowadzeniem szczepień występowała w postaci epidemii co 4-6 lat.

e) Łącznie z nowo wykrytymi w 2015 roku zakażeniami przewlekłymi.

f) Szacunek na podstawie podanych przez Narodowy Instytut Zdrowia Publicznego - Państwowy Zakład Higieny (NIZP - PZH) nowo wykrytych zakażeń przewlekłych i zachorowań ostrych w roku 2015 oraz liczby zgonów w tym roku.

g) W tym 1 zgon w grupie wiekowej 0-19.

h) Dane z roku 1960.

i) Szacunek na podstawie podanych przez NIZP -PZH nowo wykrytych zakażeń przewlekłych i zachorowań ostrych w roku 2015 oraz liczby zgonów w tym roku.

j) W tym 0 zgonów w grupie wiekowej 0-19.

Źródło: Opracowanie własne na podstawie wskazanej bibliografii.

o zapobieżenie ostrym, ogólnoustrojowym postaciom gruźlicy, np. gruźliczemu zapaleniu opon mózgowo-rdzeniowych (Szczepienia, 2018). Spadek liczby zachorowań i zgonów z powodu gruźlicy w dużym stopniu można przypisać innym czynnikom, m.in. skutecznej terapii przeciwprątkowej. 
Porównanie skutków chorób i NOP jednoznacznie przemawia za obowiązkiem stosowania szczepień. Korzyści wynikające z obowiązku szczepień zdecydowanie przewyższają nałożone na obywateli ciężary. Dlatego też można jednoznacznie stwierdzić, że ustawa o zapobieganiu i zwalczaniu chorób zakaźnych u ludzi w pełni przechodzi test proporcjonalności.

W świetle przedstawionych wyżej informacji rozważyć należy, czy ze strony państwa możliwa byłaby reakcja prawnokarna na niepoddanie się obowiązkowi szczepień. Pytanie to jest o tyle zasadne, że cały XIX rozdział ustawy z dnia 6 czerwca 1997 r. - Kodeks karny (Dz.U. z 1997 r. Nr 88, poz. 553 ze zm.; dalej: k.k.) jest poświęcony przepisom mającym ten sam cel, co przepisy wprowadzające obowiązek szczepień - ochronę życia i zdrowia. Rozważyć należy, czy osobę odmawiającą zaszczepienia siebie bądź swojego dziecka można pociągnąć do odpowiedzialności za popełnienie przestępstwa z art. 160 k.k., to jest za narażenie osoby na bezpośrednie niebezpieczeństwo utraty życia lub ciężkiego uszczerbku na zdrowiu.

Choroby objęte obowiązkiem szczepień prowadzą do zgonu lub ciężkiego uszczerbku na zdrowiu albo ze swej istoty, albo wskutek ich powikłań. Jako przykład wskazać można jedną z chorób wieku dziecięcego, odrę - 0,2\% zarażonych umiera, u 1 na 1000 dochodzi do zapalenia i obrzęku mózgu (Ściubisz, Rywczak 2017). Jak było wcześniej wspomniane, szczepionki mają wysoką, sięgającą do 99\% skuteczność, a 97\% w przypadku zapobiegającego odrze szczepienia MMR (Ściubisz, Rywczak 2017). Tak więc uchylenie się od obowiązku szczepienia sprawia, że dziecko jest kilkanaście, kilkadziesiąt razy bardziej narażone na opisane w art. 160 niebezpieczeństwo. Zastanowić się jednak należy, czy takie niebezpieczeństwo wypełnia znamię bezpośredniości. Bezpośredniość tę rozumieć trzeba jako zmianę sytuacji z bezpiecznej na taką, w której występuje wysokie prawdopodobieństwo wystąpienia negatywnych skutków dla ofiary bez dalszych działań sprawcy czynu (Marek 2010).

Okazuje się, że program szczepień ochronnych jest tak skuteczny, iż objęte nim choroby w 2015 roku przeważnie albo nie występowały - jak poliomyeltis i błonica, albo spełniały kryterium chorób rzadkich (tj. liczba zachorowań była mniejsza niż 50 na 100000 osób na rok). Wynika z tego, że w zasadzie nie obserwuje się zgonów związanych z chorobami objętymi obowiązkiem szczepień ochronnych. Trzymając się przykładu odry, na którą w roku 2015 zachorowało 41 osób, przyjąć można najprostszy model, w którym wszystkie dzieci w Polsce są zaszczepione, liczba zachorowań jest stała i taka jak w 2015, liczebność rocznika to 400000 osób, wyszczepialność to $100 \%$, skuteczność szczepionki $97 \%$, a śmiertelność odry wynosi $0,2 \%$. Wówczas, gdy jedno dziecko uniknie szczepienia, prawdopodobieństwo jego zgonu z powodu odry w ciągu całego życia wyniesie $0,0006 \%$. Podobnie w przypadku innych chorób zakaźnych, okazuje się, że osoby nieszczepione skutecznie korzystają z efektu odporności gromadnej. 
Nie da się mówić o bezpośrednim niebezpieczeństwie, kiedy zwiększenie ryzyka wystąpienia zgonu bądź odpowiednio ciężkich powikłań jest tak niskie. Wydaje się zatem, że w normalnej sytuacji nie ma możliwości zastosowania wobec osób nieszczepiących art. 160 k.k. Należy zaznaczyć, że brak możliwości skorzystania z tego artykułu nie wynika z jego nieadekwatności wobec obowiązku szczepień, ale z bieżącej sytuacji epidemiologicznej. Ma ona tendencję do systematycznego poprawiania się, w ogromnym stopniu dzięki szczepieniom właśnie. Można jednak przeanalizować teoretyczną sytuację znacznego jej pogorszenia, do czego doprowadziłoby choćby masowe uchylanie się od obowiązku szczepień. Jako hipotetyczny przykład wskazać można zachorowalność na poliomyeltis tuż przed wprowadzeniem szczepień. Szczepienia przeciwko chorobie Heinego-Medina w Polsce rozpoczęto w roku 1959 (Magdzik 2002). Poliomyeltis jest chorobą wirusową, która atakuje rogi przednie rdzenia kręgowego. Doprowadza to do zaniku nerwów odpowiadających za ruch mięśni szkieletowych. W zależności od zajętej okolicy rdzenia kręgowego prowadzi do trwałej niepełnosprawności ruchowej, a w najcięższych przypadkach do porażenia mięśni oddechowych, co kończy się albo zgonem, albo oznacza konieczność dożywotniego korzystania z aparatury podtrzymującej oddychanie. W 1958 doszło do 6090 zachorowań na najcięższą, porażenną postać poliomyeltis. Liczebności roczników urodzonych w latach 50 . były na poziomie ponad 700 tys. (Strzelecki, Witkowski 2009). Gdyby taka zapadalność utrzymała się, przy zerowej wyszczepialności, 1\% osób w ciągu dzieciństwa rozwinąłby porażenną postać choroby Heinego-Medina, umierając bądź zostając trwale okaleczonymi. Tego typu hipotetyczna sytuacja epidemiologiczna spowodowałaby, że należałoby zastosować art. 160 k.k. w przypadku rodzica odmawiającego poddania dziecka obowiązkowemu szczepieniu.

Obecny stan prawny przewiduje jednakże inną możliwość reakcji karnoprawnej na niedochowanie obowiązku szczepień. Art. 115 ustawy z dnia 20 maja 1971 r. - Kodeks wykroczeń (Dz.U. z 1971 r. Nr 12, poz. 114 ze zm.; dalej k.w.) przewiduje sankcję za niepoddanie się obowiązkowi szczepień ochronnych pomimo zastosowania środków egzekucji administracyjnej oraz za niepoddanie temu obowiązkowi osoby małoletniej lub bezradnej, nad którą sprawuje się pieczę, w formie grzywny do 1500 zł i nagany. Niemożność ścigania sprawcy takiego wykroczenia bez wcześniejszego środka administracyjno-prawnego powoduje jednak znaczne utrudnienie w karaniu sprawców takiego wykroczenia. Konieczność oczekiwania na przeprowadzenie egzekucji administracyjnej przez wojewodę znacznie i bez potrzeby wydłuża czas potrzebny do reakcji prawnokarnej. Możliwość zaskarżenia decyzji wojewody do sądu administracyjnego może bowiem wydłużyć postępowanie administracyjne na lata. Można też zadać pytanie, czy dobrem chronionym faktycznie będzie tu zdrowie publiczne, czy też jednak staje się nim pewne niedookreślone prawo organów administracji do stosowania środków władczych. Postulatem de lege ferenda byłoby usunięcie zwrotu „pomimo zastosowania środków egzekucji administracyjnej” z tego przepisu. Warto 
wspomnieć, że w poprzednim stanie prawnym istniało wykroczenie wskazane w art. 35 ustawy z dnia 6 września 2001 r. o chorobach zakaźnych i zakażeniach (Dz.U. z 2001 r. Nr 126, poz. 1384), który wprost przewidywał karę grzywny za niestosowanie się do obowiązków wynikających z tej ustawy, w tym do obowiązku poddania się szczepieniu ochronnemu.

Podsumowując, obowiązek szczepień ochronnych jest obowiązkiem wynikającym z mocy samego prawa, co do którego w obecnym stanie prawnym organem egzekucyjnym jest wojewoda. Jeśli chodzi o kompetencje Państwowej Inspekcji Sanitarnej w egzekwowaniu tego obowiązku, to wojewoda może co najwyżej powierzyć temu organowi część uprawnień na mocy art. 20 ustawy z dnia 23 stycznia 2009 r. o wojewodzie i administracji rządowej w województwie (Dz.U. z 2009 r. Nr 31, poz. 206 ze zm.). Przepisy wprowadzające obowiązek szczepień są w pełni zgodne z konstytucyjną zasadą proporcjonalności. Ich zabezpieczeniem jest art. 115 Kodeksu wykroczeń, a w sytuacji poważnego zagrożenia epidemiologicznego można za takowe uznać także art. 160 Kodeksu karnego. Postulatami proponowanymi przez autorów są: wprowadzenie przepisów umożliwiających bezpośrednio Państwowej Inspekcji Sanitarnej prowadzenie egzekucji rzeczonego obowiązku, a także zmiana znamion wykroczenia z art. 115 k.w. tak, aby nie było konieczne oczekiwanie na zakończenie postępowania administracyjnego.

\section{BIBLIOGRAFIA}

Czarkowski, Mirosław P., Barbara Kondej, Ewa Staszewska-Jakubik, Ewa Cielebąk. 2016. Szczepienia ochronne w Polsce w 2015 roku. Warszawa: Narodowy Instytut Zdrowia Publicznego - Państwowy Zakład Higieny.

Daniel, Paweł. 2014. „Egzekucja obowiązku poddania małoletniego dziecka szczepieniu ochronnemu w orzecznictwie sądów administracyjnych”. Przegląd Prawa Publicznego 4: 45-55.

Fenner, Frank, Donald A. Henderson, Isao Arita, Zdenek Jezek, Ivan Ladnyi (red). 1988. Smallpox and its eradication. Genewa: World Health Organization.

Fine, Paul E.M. 1993. „Herd Immunity: History, Theory, Practice”. Epidemiologic Reviews 15 (2): $265-302$.

Garlicki, Leszek. 2017. Polskie prawo konstytucyjne. Zarys wykładu. Warszawa: Wolters Kluwer.

Hamborsky, Jennifer, Andrew Kroger, Charles Wolfe. 2015. Epidemiology and prevention of vaccine-preventable diseases. Washington: Centers for Disease Control and Prevention (U.S. Department of Health and Human Services).

Kubiak, Rafał. 2017. Prawo medyczne. Warszawa: Wydawnictwo C.H. Beck.

Magdzik, Wiesław. 2002. „Choroba Heinego i Medina - Porażenie dziecięce - Poliomyeltis - Polio. Rozkwit i agonia choroby w dwudziestym wieku". Przeglad Epidemiologiczny 56 (4): $522-523$.

Marek, Andrzej. 2010. Kodeks karny. Komentarz. Warszawa: LEX.

Nesterowicz, Mirosław. 2016. Prawo medyczne. Toruń: Dom Organizatora TNOiK.

Strzelecki, Zbigniew, Janusz Witkowski. 2009. „Przeszłość i przyszłość demograficzna Polski” [referat]. Biuletyn Rzadowej Rady Ludnościowej 54: 33-60. 
Ściubisz, Małgorzata, Iwona Rywczak. 2017. „Ryzyko związane ze szczepieniami i chorobami, którym zapobiegają - cz. 6: odra, świnka i różyczka”. Medycyna Praktyczna - Szczepienia 2: $40-51$.

\section{Akty prawne}

Konstytucja Rzeczypospolitej Polskiej z dnia 2 kwietnia 1997 r. (Dz.U. z 1997 r. Nr 78, poz. 483 ze zm.).

Rozporządzenie Ministra Zdrowia z dnia 21 grudnia 2010 r. w sprawie niepożądanych odczynów poszczepiennych oraz kryteriów ich rozpoznawania (Dz.U. z 2010 r. Nr 254, poz. 171).

Rozporządzenie Ministra Zdrowia z dnia 18 sierpnia 2011 r. w sprawie obowiązkowych szczepień ochronnych (Dz.U. z 2011 r. Nr 182, poz. 1086 ze zm.).

Ustawa z dnia 17 czerwca 1966 r. o postępowaniu egzekucyjnym w administracji (Dz.U. z 1966 r. $\mathrm{Nr} 24$, poz. 151).

Ustawa z dnia 20 maja 1971 r. - Kodeks wykroczeń (Dz.U. z 1971 r. Nr 12, poz. 114 ze zm.).

Ustawa z dnia 14 marca 1985 r. o Państwowej Inspekcji Sanitarnej (Dz.U. z 1985 r. Nr 12, poz. 49).

Ustawa z dnia 30 sierpnia 1991 r. o zakładach opieki zdrowotnej (Dz.U. z 1991 r. Nr 91, poz. 408).

Ustawa z dnia 5 grudnia 1996 r. o zawodach lekarza i lekarza dentysty (Dz.U. z 1997 r. Nr 28, poz. 152 ze zm.).

Ustawa z dnia 6 czerwca 1997 r. - Kodeks karny (Dz.U. z 1997 r. Nr 88, poz. 553 ze zm.).

Ustawa z dnia 6 września 2001 r. o chorobach zakaźnych i zakażeniach (Dz.U. z 2001 r. Nr 126, poz. 1384).

Ustawa z dnia 6 listopada 2008 r. o prawach pacjenta i Rzeczniku Praw Pacjenta (Dz.U. z 2009 r. $\mathrm{Nr} 52$, poz. 417 ze zm.).

Ustawa z dnia 5 grudnia 2008 r. o zapobieganiu i zwalczaniu chorób zakaźnych u ludzi (Dz.U. z 2008 r. $\mathrm{Nr} 234$, poz. 1570 ze zm.).

Ustawa z dnia 23 stycznia 2009 r. o wojewodzie i administracji rządowej w województwie (Dz.U. z 2009 r. Nr 31, poz. 206).

Ustawa z dnia 15 kwietnia 2011 r. o działalności leczniczej (Dz.U. z 2011 r. Nr 112, poz. 654 ze zm.).

\section{Orzecznictwo}

Orzeczenie TK z dnia 26 kwietnia 1995 r., K 11/94, LEX nr 25538.

Wyrok NSA z dnia 6 kwietnia 2011 r., II OSK 32/11, LEX nr 852219.

Wyrok SA w Warszawie z dnia 19 października 2016 r., VII SA/Wa 2542/15, LEX nr 2159952.

Wyrok SN z dnia 8 stycznia 2016 r., V KK 306/15, LEX nr 1963649.

Wyrok WSA w Krakowie z dnia 14 lutego 2013 r., III SA/Kr 460/12, LEX nr 1343450.

Wyrok WSA w Poznaniu z dnia 1 czerwca 2017 r., IV SAB/Po 22/17, LEX nr 2341062.

\section{Inne źródła}

Szczepienia. 2018. Narodowy Instytut Zdrowia Publicznego - Państwowy Zakład Higieny. http:// szczepienia.pzh.gov.pl [dostęp 30.03.2018]. 


\title{
Michat Fita, Barttomiej Król
}

\section{OBLIGATION OF VACCINATION - LEGAL AND MEDICAL ANALYSIS}

\begin{abstract}
The authors analyze legal regulations regarding compulsory prophylactic vaccinations mentioned in the statue on preventing and fighting human infectious diseases. The analysis is concerned with constitutional, administrative, and criminal law, all devised in accordance with the present state of medical knowledge. Moreover, this work contains de lege ferenda postulates concerned with ways of ameliorating the execution of compulsory vaccinations - those postulates, according to the authors, would enhance the protection of human life and health. Introducing those changes would be crucial in face of the growing number of people who refuse to receive vaccinations or prevent their children from receiving them. Failing to recognize the importance of this situation may lead to future negative outcomes.
\end{abstract}

Keywords: medical law, vaccinations, an obligation of vaccination, exposure to danger, prevention of infectious diseases. 